\title{
CORRECTION
}

\section{Correction: Patterns of infection and impact on outcome in haematology patients admitted to intensive care}

Ricardo Jose*, Isla MacDonald, Paul Pfeffer, Steve Shaw, Christopher Kibbler and Banwari Agarwal

See related abstract by José et al., http://ccforum.com/content/15/S1/P496

After publication of their conference abstract [1], the authors found the following error:

In the 'Results' section, "The most commonly identified bacteria were Pseudomonas aeruginosa (15.4\%) and Enterococcus faecalis (11.3\%); viruses were cytomegalovirus (CMV) (17.5\%) and respiratory syncytial virus (RSV) (17.5\%); and fungi were Candida species (6.2\%)", the proportion of Enterococcus faecalis should be $14.4 \%$ and for RSV it should be $2 \%$.

Competing interests

The authors declare that they have no competing interests.
Published: 19 July 2012

\section{Reference}

1. José R, McDonald I, Pfeffer P, Shaw S, Kibbler C, Agarwal B: Patterns of infection and impact on outcome in haematology patients admitted to intensive care. Crit Care 2011, 15(Suppl 1):P496.

doi:10.1186/cc11423

Cite this article as: José $R$, et al.: Correction: Patterns of infection and impact on outcome in haematology patients admitted to intensive care. Critical Care 2012, 16:434.
*Correspondence: rjose@doctors.org.uk

Royal Free Hospital, London, UK 